\title{
Effect of Immune-Enhancing Enteral Nutrition Enriched with or without Beta-Glucan on Immunomodulation in Critically Ill Patients
}

\author{
Jae Gil Lee ${ }^{1}$, Young Sam Kim ${ }^{2}$, Young Ju Lee ${ }^{3,4}$, Hyeon Yeong Ahn ${ }^{5}$, Minjoo Kim ${ }^{5}$, \\ Minkyung $\mathrm{Kim}^{3,4}$, Min Jung Cho ${ }^{3,4}$, Younsoo Cho ${ }^{6}$ and Jong Ho Lee ${ }^{3,4,5, *}$ \\ 1 Department of Surgery, Yonsei University College of Medicine, Seoul 03722, Korea; jakii@yuhs.ac \\ 2 Department of Internal Medicine, Yonsei University College of Medicine, Seoul 03722, Korea; \\ ysamkim@yuhs.ac \\ 3 National Leading Research Laboratory of Clinical Nutrigenetics/Nutrigenomics, Department of Food and \\ Nutrition, College of Human Ecology, Yonsei University, Seoul 03722, Korea; juny9558@naver.com (Y.J.L.); \\ mkkim0106@yonsei.ac.kr (M.K.); wm5156@hanmail.net (M.J.C.) \\ 4 Department of Food and Nutrition, Brain Korea 21 PLUS Project, College of Human Ecology, \\ Yonsei University, Seoul 03722, Korea \\ 5 Research Center for Silver Science, Institute of Symbiotic Life-TECH, Yonsei University, Seoul 03722, Korea; \\ vitaminahy@naver.com (H.Y.A.); minjookim@yonsei.ac.kr (M.K.) \\ 6 Department of Nutrition, Yonsei University Health System, Seoul 03722, Korea; yscho@yuhs.ac \\ * Correspondence: jhleeb@yonsei.ac.kr; Tel.: +82-2-2123-3122
}

Received: 15 March 2016; Accepted: 30 May 2016; Published: 2 June 2016

\begin{abstract}
We investigated whether high-protein enteral nutrition with immune-modulating nutrients (IMHP) enriched with $\beta$-glucan stimulates immune function in critically ill patients. In a randomized double-blind placebo-controlled study, 30 patients consumed one of three types of enteral nutrition: a control or IMHP with and without $\beta$-glucan. The IMHP with $\beta$-glucan group showed increases in natural killer (NK) cell activities relative to the baseline, and greater increases were observed in NK cell activities relative to the control group after adjusting for age and gender. The IMHP groups with and without $\beta$-glucan had greater increases in serum prealbumin and decreases in high-sensitivity C-reactive protein (hs-CRP) than the control group. The control group had a greater decrease in peripheral blood mononuclear cell (PBMC) interleukin (IL)-12 production than the IMHP with and without $\beta$-glucan groups. In all patients, the change $(\Delta)$ in hs-CRP was correlated with $\Delta$ prealbumin and $\triangle$ PBMC IL-12, which were correlated with $\Delta$ NK cell activity and $\Delta$ prealbumin. This study showed beneficial effects of a combination treatment of $\beta$-glucan and IMHP on NK cell activity. Additionally, strong correlations among changes in NK cell activity, PBMC IL-12, and hs-CRP suggested that $\beta$-glucan could be an attractive candidate for stimulating protective immunity without enhanced inflammation (ClinicalTrials.gov: NCT02569203).
\end{abstract}

Keywords: beta-glucan; enteral nutrition; ICU; NK cell; immune system; inflammation

\section{Introduction}

Critically ill patients are at risk of nutritional deficiency; thus, supportive nutrition is required for most intensive care unit (ICU) patients, with enteral nutrition preferred over parenteral nutrition [1,2]. Enteral nutrition with immune-modulating nutrients, such as $\omega-3$ fatty acids, selenium, and antioxidants, may modulate pathophysiological processes in critical illness, such as inflammatory and oxidative stress responses and impaired immune function [3,4]. The immunomodulatory effect of the Lentinula edodes (shiitake) mushroom has been conducted in previous studies and there are various biological active compounds in mushrooms. $\beta$-glucan, which is derived from mushrooms, is known 
as one of the biological active compounds in mushrooms [5-8]. Recently, $\beta$-glucan polysaccharides have been reported to stimulate the immune system, modulating humoral and cellular immunity and thereby having beneficial effects in fighting infections. Previous clinical studies conducted the immunomodulatory effects of $\beta$-glucan in patients with cancer, allergies, or respiratory tract infection [9-11]. Richter et al. reported that short-term oral application of $\beta$-glucan significantly stimulated mucosal immunity of children with chronic respiratory problems in a series of clinical trials $[12,13]$. $\beta$-glucan is thought to mediate its stimulatory effects through the activation of various immune system components, including macrophages, neutrophils, natural killer (NK) cells, and lymphocytes [14-17].

Although previous data clearly provide support for an immunomodulatory effect of $\beta$-glucan, there are few clinical studies on the immunomodulatory effect of $\beta$-glucan in critically ill patients. More clinical data are therefore clearly needed on the efficacy of orally supplemented $\beta$-glucan as an immune modulator in critically ill patients. The objective of this study was to determine whether high-protein ( $24 \%$ of total calories from protein) enteral nutrition of immune-modulating nutrients (e.g., $\omega-3$ fatty acids, selenium, and antioxidants) (IMHP) enriched with $\beta$-glucan stimulates immune function compared with standard enteral nutrition (control: $20 \%$ of total calories from protein) or IMHP without $\beta$-glucan in critically ill patients.

\section{Materials and Methods}

\subsection{Participants}

From April 2014 to September 2015, 30 critically ill patients were enrolled in this study after admission to the ICU at Yonsei University Severance Hospital. The ICU patients were composed of 18 patients with pulmonary disease and 12 patients with trauma. Disease severity was evaluated by the Acute Physiology and Chronic Health Evaluation (APACHE) II score [18]. All patients were treated according to the appropriate guidelines $[19,20]$. Informed consent was provided by a close family member. This investigation was approved by the Institutional Review Board at Yonsei University Severance Hospital, Seoul, Korea (Approval number: 4-2013-0902). All comorbidities and histories of the study participants were recorded (ClinicalTrials.gov: NCT02569203) [21].

\subsection{Randomization and Intervention}

Using computer-generated randomization lists, 30 critically ill patients were randomized to receive one of three types of enteral nutrition: standard enteral nutrition (control), high-protein enteral nutrition with immune-modulating nutrients (IMHP) enriched with $\beta$-glucan, or IMHP without $\beta$-glucan. The ready-to-use control and IMHP with and without $\beta$-glucan products had identical packaging with no differences in appearance, texture, or smell. Investigators and clinicians were blinded to the treatment groups. Patients assigned to the control group received a standard formula tube feed (protein:fat:carbohydrate from total calories $=20 \%: 30 \%: 50 \%$; Dr. Chung's Food Co., LTD, Cheongju, Korea). Those assigned to the IMHP group received $\omega-3$ fatty acid $(3.3 \mathrm{~g} / \mathrm{L})-$ and antioxidant $(110 \mu \mathrm{g} / \mathrm{L}$ selenium)-enriched high protein tube feed (protein:fat:carbohydrate from total calories $=24 \%: 30 \%: 46 \%$; Dr. Chung's Food Co., LTD, Korea). Those assigned to the IMHP group with $\beta$-glucan received $\beta$-glucan-enriched IMPH tube feed (experimental product; Dr. Chung's Food Co., LTD, Korea).

$\beta$-glucan derived from mushrooms (Lentinus edodes) and the content of $\beta$-glucan in mushroom extract was $13 \%$. The $\beta$-glucan used in this study was not concentrated; instead, the whole mushroom extract was included in enteral nutrition product for IMHP with $\beta$-glucan group. IMHP with $\beta$-glucan group was designed to contain $50 \mathrm{mg}$ of $\beta$-glucan per $200 \mathrm{kcal}(0.25 \mathrm{mg} / \mathrm{kcal})$ from the mushroom extract, and the rest was contents to the standard formula used in the control group, but fortified with $\omega-3$ fatty acid, antioxidants, and enriched high protein. The enteral nutrition product for IMHP group 
was designed to contain exactly the same contents as those for the IMHP group with $\beta$-glucan except for the $\beta$-glucan content. The composition of the enteral nutrition product was indicated in Table 1.

Table 1. Composition of the enteral nutrition product.

\begin{tabular}{|c|c|c|c|}
\hline Nutrient & Control & IMHP with $\beta$-Glucan & IMHP \\
\hline Calories (kcal) & 200 & 200 & 200 \\
\hline Protein $(\mathrm{g})$ & 10.0 & 12.0 & 12.0 \\
\hline Total fat (g) & 6.7 & 6.7 & 6.7 \\
\hline Total carbohydrate (g) & 28.5 & 23.0 & 23.0 \\
\hline Vitamin A ( $\mu \mathrm{gRE})$ & 150.00 & 150.00 & 150.00 \\
\hline VitaminB1 (mg) & 0.24 & 0.24 & 0.24 \\
\hline VitaminB2 (mg) & 0.30 & 0.30 & 0.30 \\
\hline VitaminB6 (mg) & 0.30 & 0.30 & 0.30 \\
\hline VitaminB12 $(\mu \mathrm{g})$ & 0.48 & 0.48 & 0.48 \\
\hline Vitamin C (mg) & 20.00 & 40.00 & 40.00 \\
\hline VitaminD3 ( $\mu \mathrm{g})$ & 1.00 & 1.00 & 1.00 \\
\hline Vitamin E (mg $\alpha-\mathrm{TE})$ & 2.00 & 4.80 & 4.80 \\
\hline VitaminK1 ( $\mu \mathrm{g})$ & 9.75 & 15.00 & 15.00 \\
\hline Folic acid $(\mu \mathrm{g})$ & 80.00 & 80.00 & 80.00 \\
\hline Niacin (mg) & 3.20 & 3.20 & 3.20 \\
\hline Biotin $(\mu \mathrm{g})$ & 6.00 & 6.00 & 6.00 \\
\hline Pantothenic acid (mg) & 1.00 & 1.00 & 1.00 \\
\hline Calcium (mg) & 140.00 & 150.00 & 150.00 \\
\hline Phosphorus (mg) & 140.00 & 140.00 & 140.00 \\
\hline Magnesium (mg) & 58.00 & 44.20 & 44.20 \\
\hline Zinc (mg) & 2.00 & 4.00 & 4.00 \\
\hline Iron (mg) & 2.00 & 2.00 & 2.00 \\
\hline Sodium (mg) & 155.00 & 141.35 & 141.35 \\
\hline Chloride (mg) & 170.00 & 121.20 & 121.20 \\
\hline Potassium (mg) & 260.00 & 240.39 & 240.39 \\
\hline Manganese (mg) & 0.46 & 1.60 & 1.60 \\
\hline Iodine $(\mu \mathrm{g})$ & 19.50 & 30.00 & 30.00 \\
\hline Copper (mg) & 0.10 & 0.32 & 0.32 \\
\hline Selenium ( $\mu \mathrm{g})$ & 0.00 & 22.00 & 22.00 \\
\hline Chromium $(\mu \mathrm{g})$ & 0.00 & 5.00 & 5.00 \\
\hline Molybdenum ( $\mu \mathrm{g})$ & 0.00 & 2.50 & 2.50 \\
\hline Taurine (mg) & 22.00 & 22.00 & 22.00 \\
\hline L-Carnitine (mg) & 22.00 & 22.00 & 22.00 \\
\hline Choline (mg) & 73.00 & 73.00 & 73.00 \\
\hline$\beta$-glucan (mg) & 0.00 & 50.00 & 0.00 \\
\hline
\end{tabular}

Enteral nutrition was initiated within $24 \mathrm{~h}$ of ICU admission. Enteral feeding was delivered at a constant rate to achieve a minimum of $50 \%$ basal energy expenditure (BEE; determined using the Harris-Benedict equation) $\times 1.2$ within the first $12 \mathrm{~h}$ [22]. If well tolerated, enteral nutrition was advanced to achieve a BEE $\times 1.2$ within $48 \mathrm{~h}$. Complementary feeding with enteral or parenteral nutrition was allowed for an initial $48 \mathrm{~h}$. From the third day, the patient received a minimum of $75 \%$ of BEE $\times 1.2$. The enteral diet was delivered continuously for seven days during the ICU stay at a rate not exceeding BEE $\times 1.2$. The daily enteral intake was recorded to obtain the total volume and calories delivered to the patients. The data on daily total calorie intake were abstracted from the medical records. Blood samples were collected at the baseline and after seven days.

\subsection{Anthropometric Parameters and Blood Collection}

Body mass index (BMI) was measured with an Inbody S10 bedside-type body composition analyzer (Inbody, Cheonan, Republic of Korea) in a supine state in the morning. Venous blood 
specimens were collected in EDTA-treated and plain tubes and centrifuged to obtain plasma and serum. The collected blood samples were stored at $-70^{\circ} \mathrm{C}$ until analysis.

\subsection{Serum Lipid Profiles and Glucose}

Serum triglyceride and serum total cholesterol concentrations were analyzed by enzymatic assays using a Hitachi 7600 autoanalyzer (Hitachi, Tokyo, Japan). Serum high-density lipoprotein (HDL)-cholesterol concentrations were determined by selective inhibition using a Hitachi 7600 autoanalyzer. Low-density lipoprotein (LDL)-cholesterol concentrations were calculated indirectly using the Friedwald formula; i.e., LDL-cholesterol $=$ total cholesterol - [HDL-cholesterol + (triglyceride/5)] for subjects with serum triglyceride concentrations $<400 \mathrm{mg} / \mathrm{dL}$. Serum glucose concentrations were measured according to the hexokinase method on a Hitachi 7600 autoanalyzer.

\subsection{Serum Nutritional Status}

Serum albumin concentrations were analyzed through the BCG method using an ALB kit (Siemens, Tarrytown, NY, USA) with an ADVIA 2400 autoanalyzer (Siemens, Tarrytown, NY, USA). Serum prealbumin concentrations were determined by an immunoturbidimetric assay using a COBAS INTEGRA autoanalyzer (Roche-BM, Rotkreuz, Switzerland).

\subsection{Serum Liver and Renal Function}

Serum glutamic oxaloacetic transaminase (GOT) and serum glutamic pyruvate transaminase (GPT) were analyzed through the IFCC UV method with a Hitachi 7600 autoanalyzer. Serum gamma-glutamyl transpeptidase ( $\gamma$-GTP) was measured according to a modified Szanz method on a Hitachi 7600 autoanalyzer. Blood urea nitrogen (BUN) was determined by a kinetic UV assay for urea/urea nitrogen using a Hitachi 7600 autoanalyzer. Creatinine was analyzed through the creatinine Jaffe method on a Hitachi 7600 autoanalyzer.

\subsection{Leukocyte Count and Serum High-Sensitivity C-Reactive Protein}

Leukocyte count was determined using the HORIBA ABX diagnostic analyzer (HORIBA ABX SAS, ParcEuromedicine, Montpellier, France). Serum high-sensitivity C-reactive protein (hs-CRP) levels were measured with a kit from the N-Assay LA CRP-S D-TYPE (Nittobo, Tokyo, Japan) with a Hitachi 7600 autoanalyzer.

\subsection{Peripheral Blood Mononuclear Cells}

To analyze the cytokine assay in peripheral blood mononuclear cells (PBMCs) supernatants, we isolated PBMCs from whole blood samples. Whole blood samples were mixed with the same volume of RPMI 1640 (Gibco, Thermo Fisher Scientific, Waltham, MA, USA) and gently overlaid on the histopaque (Sigma-Aldrich, Irvine, UK) and then centrifuged ( $20 \mathrm{~min}, 1800 \mathrm{rpm}, 15^{\circ} \mathrm{C}$ ). After separation, a thin layer of buffer coat was isolated and washed twice with RPMI 1640. The pellet was resuspended in RPMI 1640 supplemented with penicillin streptomycin (Gibco, Thermo Fisher Scientific, Waltham, MA, USA). The isolated PBMCs were cultured in RPMI 1640 supplemented with $10 \%$ fetal bovine serum (Gibco, Thermo Fisher Scientific, Waltham, MA, USA), seeded into 12-well plates $\left(1.0 \times 10^{6}\right.$ cells $\left./ \mathrm{mL}\right)$, and incubated at $37^{\circ} \mathrm{C}$ under $5 \% \mathrm{CO}_{2}$ for no more than $46 \mathrm{~h} \pm 30 \mathrm{~min}$. After incubation, the supernatants were collected and stored at $-80^{\circ} \mathrm{C}$.

\subsection{Cytokine Assay in Serum and PBMC Supernatants}

Interferon (IFN)- $\gamma$ was measured with a kit from an IFN gamma High-Sensitivity Human ELISA Kit (Abcam plc-Cambridge Science Park, Cambridge, UK) according to the manufacturer's instructions. Interleukin (IL)-12 levels were analyzed by a High-Sensitivity Human IL-12 (P70) ELISA kit (Genway Biotech Inc., San Diego, CA, USA) using a Victor $\times 52030$ multilabel plate reader (PerkinElmer, 
Hopkinton, MA, USA) at $450 \mathrm{~nm}$. IL-6, IL-1 $\beta$, and tumor necrosis factor (TNF)- $\alpha$ levels in serum and PBMC supernatants were measured using the Bio-Plex ${ }^{\mathrm{TM}}$ Reagent Kit (Bio-Rad Laboratories, Hercules, CA, USA).

\subsection{NK Cell Activity}

Isolated PBMCs from the whole blood samples were incubated with K562 cells to analyze the cytotoxic activity of NK cells. A whole blood sample was mixed with the same volume of RPMI medium 1640 (Gibco, Thermo Fisher Scientific, Waltham, MA), then gently overlaid on Histopaque ${ }^{\circledR} 1077$ (Sigma-Aldrich, Irvine, UK) and centrifuged for $20 \mathrm{~min}$ at $1800 \mathrm{rpm}$ at $15^{\circ} \mathrm{C}$. After separation, a buffer coat layer was isolated, washed once with RPMI 1640 medium, and then resuspended in $1 \mathrm{~mL}$ of $10 \%$ fetal bovine serum. The isolated PBMCs (effector cell, E) were seeded into 96-well plates at ratios of 5:1 and 2.5:1 with the K562 cells $\left(2 \times 10^{4}\right.$ cells/well) (target cell, T) and then incubated at $37^{\circ} \mathrm{C}$ under $5 \% \mathrm{CO}_{2}$ for more than $4 \mathrm{~h}$. The cytolytic activities of NK cells were analyzed via the CytoTox $96^{\circledR}$ Non-Radioactive Cytotoxicity Assay Kit (Promega Co., Fitchburg, WI, USA) according to the manufacturer's instructions. The color reactions were read at $490 \mathrm{~nm}$ using a Victor $\times 52030$ multilabel plate reader (PerkinElmer, Hopkinton, MA, USA), and the results were calculated by the following formula:

$$
\% \text { Cytotoxicity }=\frac{\text { Experimental-Effector Spontaneous-Target Spontaneous }}{\text { Target Maximum-Target Spontaneous }} \times 100
$$

\subsection{Statistical Analysis}

Statistical analysis was performed using SPSS version 21.0 (IBM/SPSS Corp., Chicago, IL, USA). The logarithmic transformation was performed on skewed variables. We compared the parameters at the baseline and follow-up, and net change (difference from the baseline) among the control, IMHP enriched with $\beta$-glucan. And IMHP groups by using the Kruskal-Wallis test and the Mann-Whitney U-test with Bonferroni correction. The Wilcoxon test was evaluated to compare the effects of the intervention within each group. A general linear model test was applied to adjust for potential confounding factors. The Spearman correlation coefficient was used to examine relationships between variables. A heat map was generated to visualize correlations among variables. The results were expressed as the mean \pm standard error (SE). A $p$-value $<0.05$ was considered statistically significant.

\section{Results}

\subsection{Clinical Characteristics}

This study enrolled 30 patients. Eight patients (three control, two IMHP with $\beta$-glucan, and three IMHP) dropped out of the study. The major reasons for exclusion were the inability to meet the caloric goal, withdrawn consent for the clinical trial, and death by multiple organ failure. Table 2 shows the general and biochemical characteristics of the control and IMHP with and without $\beta$-glucan groups. No statistically significant differences among the three groups were observed at the baseline with regard to age, gender distribution, APACHE II score, and total calorie intake (day 1, day 3, and day 7). Estimated average daily intake of $\beta$-glucan was $232.8 \mathrm{mg}$ in IMHP with $\beta$-glucan group. After adjustment for age and gender distribution, no significant differences among the three groups were observed at the baseline and at the seven-day follow-up with regard to BMI, serum glucose, triglycerides, total cholesterol, HDL, LDL, leukocyte counts, and serum albumin. After seven days of treatment, patients in the IMHP group showed significant increases in serum concentrations of total cholesterol, LDL cholesterol, and albumin and patients in the control group showed a significant elevation in leukocyte counts (Table 2). 
Table 2. Clinical characteristics in the control and in IMHP groups with and without $\beta$-glucan.

\begin{tabular}{|c|c|c|c|c|c|c|c|c|}
\hline \multirow{3}{*}{ Variables } & \multicolumn{6}{|c|}{ Total $(n=22)$} & \multirow{3}{*}{$p^{a}$} & \multirow{3}{*}{$p^{b}$} \\
\hline & \multicolumn{2}{|c|}{ Control $(n=7)$} & \multicolumn{2}{|c|}{ IMHP with $\beta$-Glucan $(n=8)$} & \multicolumn{2}{|c|}{ IMHP $(n=7)$} & & \\
\hline & Baseline & Follow-up & Baseline & Follow-up & Baseline & Follow-up & & \\
\hline Age (year) & \multicolumn{2}{|c|}{$53.7 \pm 6.18$} & \multicolumn{2}{|c|}{$64.1 \pm 6.03$} & & 0.141 & \\
\hline Male/Female n, (\%) & \multicolumn{2}{|c|}{$4(57.1) / 3(42.9)$} & \multicolumn{2}{|c|}{$5(62.5) / 3(37.5)$} & \multicolumn{2}{|c|}{$6(85.7) / 1(14.3)$} & 0.488 & \\
\hline BMI $\left(\mathrm{kg} / \mathrm{m}^{2}\right)$ & $24.1 \pm 1.31$ & $23.4 \pm 1.38$ & $22.1 \pm 1.20$ & $21.9 \pm 1.37$ & $20.8 \pm 1.50$ & $20.2 \pm 1.39$ & 0.213 & 0.114 \\
\hline APACHE II score & \multicolumn{2}{|c|}{$16.7 \pm 3.07$} & \multicolumn{2}{|c|}{$16.9 \pm 3.39$} & \multicolumn{2}{|c|}{$18.5 \pm 2.69$} & 0.862 & \\
\hline \multicolumn{9}{|l|}{ TCI $(\mathrm{kcal} / \mathrm{d})$, mean } \\
\hline Day 1 & \multicolumn{2}{|c|}{$736.3 \pm 176.0$} & \multicolumn{2}{|c|}{$738.1 \pm 211.5$} & \multicolumn{2}{|c|}{$790.3 \pm 129.1$} & 0.688 & \\
\hline Day 3 & \multirow{2}{*}{\multicolumn{2}{|c|}{$\begin{array}{l}1253.5 \pm 214.3 \\
1507.7 \pm 157.2\end{array}$}} & \multirow{2}{*}{\multicolumn{2}{|c|}{$\begin{array}{c}1191.0 \pm 69.8 \\
1065.9+153.3\end{array}$}} & \multicolumn{2}{|c|}{$1059.3 \pm 151.1$} & 0.546 & \\
\hline Day 7 & & & & & 1102.0 & $=156.7$ & 0.170 & \\
\hline Glucose $(\mathrm{mg} / \mathrm{dL})^{\S}$ & $136.1 \pm 8.40$ & $143.1 \pm 5.86$ & $179.0 \pm 29.3$ & $173.8 \pm 29.1$ & $306.9 \pm 117.4$ & $154.6 \pm 17.4$ & 0.052 & 0.959 \\
\hline Triglyceride $(\mathrm{mg} / \mathrm{dL})^{\S}$ & $104.0 \pm 19.6$ & $79.3 \pm 8.83$ & $116.3 \pm 16.3$ & $109.0 \pm 12.1$ & $79.0 \pm 13.6$ & $84.4 \pm 11.2$ & 0.335 & 0.145 \\
\hline Total-cholesterol $(\mathrm{mg} / \mathrm{dL})^{\S}$ & $105.7 \pm 10.9$ & $118.4 \pm 13.2$ & $108.0 \pm 13.2$ & $132.0 \pm 8.85$ & $112.0 \pm 13.9$ & $145.0 \pm 7.75^{*}$ & 0.998 & 0.293 \\
\hline HDL-cholesterol $(\mathrm{mg} / \mathrm{dL})^{\S}$ & $27.9 \pm 6.34$ & $31.6 \pm 4.08$ & $25.9 \pm 4.67$ & $24.9 \pm 3.54$ & $34.6 \pm 4.19$ & $38.6 \pm 3.88$ & 0.645 & 0.057 \\
\hline LDL-cholesterol $(\mathrm{mg} / \mathrm{dL})^{\oint}$ & $57.1 \pm 7.76$ & $71.0 \pm 12.7$ & $58.9 \pm 11.7$ & $85.3 \pm 7.69$ & $61.6 \pm 12.6$ & $89.4 \pm 6.71 *$ & 0.924 & 0.526 \\
\hline Leukocyte counts $\left(\mathrm{X} 10^{3} / \mu \mathrm{L}\right)^{\oint}$ & $6.99 \pm 0.48$ & $12.2 \pm 2.26^{*}$ & $12.3 \pm 2.21$ & $12.7 \pm 2.24$ & $12.9 \pm 1.83$ & $10.8 \pm 1.28$ & 0.089 & 0.839 \\
\hline Serum albumin $(\mathrm{mg} / \mathrm{dL})^{\oint}$ & $2.71 \pm 0.20$ & $2.94 \pm 0.21$ & $2.83 \pm 0.10$ & $2.94 \pm 0.18$ & $2.69 \pm 0.23$ & $2.93 \pm 0.19 *$ & 0.722 & 0.979 \\
\hline
\end{tabular}

Mean \pm SE. ${ }^{\S}$ tested by logarithmic transformation, $p^{a}$-values derived from Kruskal-Wallis test at the baseline. $p^{b}$-values derived from Kruskal-Wallis test in follow-up. ${ }^{*} p<0.05$ derived from Willcoxon test. IMHP: high-protein enteral nutrition with immune-modulating nutrients. BMI: body mass index. TCI: total calorie intake. HDL: high-density lipoprotein. LDL: low-density lipoprotein. 
3.2. Effects on NK Cell Activity and Serum Prealbumin Following Seven Days of Tube Feeding of the Control and the IMHP Groups with and without $\beta-$ Glucan

NK cell activities (\%) were measured based on E:T ratios of 5:1 or 2.5:1. As shown in Table 3, no significant differences were found in the NK cell activities in both conditions measured at the baseline among the three groups. NK cell activities at the 5:1 or 2.5:1 E:T ratios were significantly increased in the IMHP with $\beta$-glucan group at seven days compared to the baseline. When we compared the changes among the three groups, the IMHP with $\beta$-glucan group had greater increases in NK cell activity at a ratio of E:T $=5: 1$ than the control group before $(p=0.019)$ and after $(p=0.037)$ adjusting for age and gender. Additionally, the IMHP with $\beta$-glucan group had greater increases in NK cell activity at ratio of E:T $=2.5: 1(p=0.034)$ than the control group; however, only an increasing tendency remained after adjusting for age and gender distribution $(p=0.055)$.

No significant differences were found in serum prealbumin concentrations at the baseline among the three groups (Table 3). Serum prealbumin concentrations were significantly increased in the IMHP with $\beta$-glucan group and IMHP group at seven days compared to the baseline. When we compared the changes among the three groups, the IMHP with $\beta$-glucan group and IMHP group had greater increases in serum prealbumin concentrations than the control group before $(p=0.002)$ and after $(p=0.001)$ adjusting for age and gender. The IMHP group had the greatest increase in serum prealbumin concentrations among the three groups. At seven days, serum prealbumin concentrations were higher in the IMHP group than those in the IMHP with $\beta$-glucan group and the control group $(p=0.017)$.

\subsection{Effects on Serum CRP and Cytokines and PBMC Cytokine Production Following Seven Days of Tube} Feeding in the Control and the IMHP Groups with and without $\beta$-Glucan

As shown in Table 3, no significant differences were found in serum hs-CRP and cytokines and PBMC cytokine production at the baseline among the three groups. Serum CRP concentrations were significantly decreased in the IMHP with $\beta$-glucan group and the IMHP group at seven days compared to the baseline. When we compared the changes among the three groups, the IMHP with $\beta$-glucan group and the IMHP group had greater decreases in serum CRP concentrations than the control group before $(p=0.002)$ and after $(p=0.006)$ adjusting for age and gender. The IMHP group had the greatest decrease in serum CRP concentrations among the three groups. At seven days, serum CRP concentrations were lower in the IMHP group than those in the IMHP with $\beta$-glucan group and control group $(p=0.006)$.

PBMC IL-12 production was significantly decreased in the control group at seven days compared to the baseline. When we compared the changes in PBMC IL-12 among the three groups, the control group had a greater decrease in IL-12 release from PBMC than the IMHP with $\beta$-glucan group and the IMHP group before $(p=0.004)$ and after adjusting for age and gender $(p=0.003)$. At seven days, the PBMC IL-6 level was significantly higher in the control group than in the IMHP group $(p=0.046)$ (Table 3). 
Table 3. NK cell activity, prealbumin, serum, and PBMC cytokines in the control and the IMHP groups with and without $\beta$-glucan.

\begin{tabular}{|c|c|c|c|c|c|c|c|c|c|c|}
\hline \multirow{3}{*}{ Variables } & \multicolumn{6}{|c|}{ Total $(n=22)$} & \multirow{3}{*}{$p^{a}$} & \multirow{3}{*}{$p^{b}$} & \multirow{3}{*}{$p^{c}$} & \multirow{3}{*}{$p^{d}$} \\
\hline & \multicolumn{2}{|c|}{ Control $(n=7)$} & \multicolumn{2}{|c|}{ IMHP with $\beta$-Glucan $(n=8)$} & \multicolumn{2}{|c|}{ IMHP $(n=7)$} & & & & \\
\hline & Baseline & Follow-up & Baseline & Follow-up & Baseline & Follow-up & & & & \\
\hline NK cell activity 5:1 (\%) & $13.6 \pm 3.69$ & $12.7 \pm 5.62$ & $11.0 \pm 2.40$ & $31.4 \pm 6.36^{*}$ & $10.7 \pm 7.41$ & $18.2 \pm 4.63$ & 0.266 & 0.155 & & \\
\hline Change & \multicolumn{2}{|c|}{$-0.86 \pm 4.17^{b}$} & \multicolumn{2}{|c|}{$20.4 \pm 5.93^{a}$} & \multicolumn{2}{|c|}{$7.47 \pm 3.59^{a, b}$} & & & 0.019 & 0.037 \\
\hline NK cell activity $2.5: 1(\%)^{\oint}$ & $14.1 \pm 2.14$ & $11.8 \pm 3.60$ & $9.88 \pm 5.14$ & $29.3 \pm 4.76^{*}$ & $7.56 \pm 5.37$ & $18.4 \pm 6.11$ & 0.841 & 0.059 & & \\
\hline Change & \multicolumn{2}{|c|}{$-2.34 \pm 3.08^{b}$} & \multicolumn{2}{|c|}{$19.4 \pm 6.67^{a}$} & \multicolumn{2}{|c|}{$10.8 \pm 6.18^{a, b}$} & & & 0.034 & 0.055 \\
\hline Prealbumin $(\mathrm{mg} / \mathrm{dL})^{\oint}$ & $11.9 \pm 2.15$ & $10.9 \pm 1.86^{b}$ & $10.4 \pm 0.84$ & $13.3 \pm 0.80^{b, *}$ & $9.00 \pm 1.21$ & $19.3 \pm 1.87^{a, *}$ & 0.589 & 0.017 & & \\
\hline Change & \multicolumn{2}{|c|}{$-1.00 \pm 1.05^{\bar{c}}$} & \multicolumn{2}{|c|}{$2.88 \pm 0.83^{b}$} & \multicolumn{2}{|c|}{$10.3 \pm 2.12^{a}$} & & & 0.002 & 0.001 \\
\hline hs-CRP (mg/dL) $)^{\oint}$ & $84.7 \pm 20.0$ & $99.7 \pm 18.9^{a}$ & $130.3 \pm 33.0$ & $65.7 \pm 13.9^{a, *}$ & $164.1 \pm 23.8$ & $19.8 \pm 9.87^{b, *}$ & 0.093 & 0.006 & & \\
\hline Change & \multicolumn{2}{|c|}{$15.0 \pm 11.9^{a}$} & \multicolumn{2}{|c|}{$-64.6 \pm 24.5^{b}$} & \multicolumn{2}{|c|}{$-144.3 \pm 28.5^{b}$} & & & 0.002 & 0.006 \\
\hline \multicolumn{11}{|l|}{ Serum } \\
\hline $\mathrm{IL}-12(\mathrm{pg} / \mathrm{mL})$ & $9.54 \pm 8.84$ & $7.67 \pm 4.58$ & $3.21 \pm 3.21$ & $10.6 \pm 9.55$ & $3.90 \pm 3.90$ & $0.00 \pm 0.00$ & 0.696 & 0.193 & & \\
\hline IFN- $\gamma(\mathrm{pg} / \mathrm{mL})$ & $0.03 \pm 0.03$ & $0.03 \pm 0.03$ & $0.24 \pm 0.24$ & $0.28 \pm 0.28$ & $0.00 \pm 0.00$ & $0.00 \pm 0.00$ & 0.613 & 0.613 & & \\
\hline $\mathrm{TNF}-\alpha(\mathrm{pg} / \mathrm{mL})^{\oint}$ & $6.23 \pm 1.87$ & $3.78 \pm 0.46$ & $6.55 \pm 1.39$ & $6.06 \pm 1.79$ & $7.80 \pm 0.81$ & $6.67 \pm 1.79$ & 0.889 & 0.634 & & \\
\hline IL-6 $(\mathrm{pg} / \mathrm{mL})^{\oint}$ & $66.8 \pm 23.2$ & $49.5 \pm 23.6$ & $39.5 \pm 9.94$ & $23.5 \pm 6.07$ & $72.3 \pm 51.6$ & $13.2 \pm 3.02$ & 0.456 & 0.090 & & \\
\hline $\mathrm{IL}-1 \beta(\mathrm{pg} / \mathrm{mL})^{\oint}$ & $7.27 \pm 5.65$ & $4.31 \pm 3.47$ & $0.82 \pm 0.08$ & $0.75 \pm 0.07$ & $0.92 \pm 0.17$ & $1.05 \pm 0.34$ & 0.217 & 0.321 & & \\
\hline \multicolumn{11}{|l|}{ Nonstimulated PBMCs } \\
\hline IL-12 (pg/mL) & $24.1 \pm 6.06$ & $12.2 \pm 5.47^{*}$ & $15.3 \pm 4.73$ & $20.2 \pm 4.55$ & $18.8 \pm 2.19$ & $20.7 \pm 3.16$ & 0.519 & 0.305 & & \\
\hline Change & \multicolumn{2}{|c|}{$-11.9 \pm 3.38^{\bar{b}}$} & \multicolumn{2}{|c|}{$4.83 \pm 2.61^{a}$} & \multicolumn{2}{|c|}{$1.89 \pm 1.68^{a}$} & & & 0.004 & 0.003 \\
\hline IFN- $\gamma(\mathrm{pg} / \mathrm{mL})$ & $1.00 \pm 0.31$ & $0.67 \pm 0.19$ & $0.54 \pm 0.17$ & $0.75 \pm 0.23$ & $0.78 \pm 0.18$ & $0.76 \pm 0.20$ & 0.520 & 0.999 & & \\
\hline $\mathrm{TNF}-\alpha(\mathrm{pg} / \mathrm{mL})^{\oint}$ & $9.66 \pm 4.98$ & $25.4 \pm 16.9$ & $3.17 \pm 2.06$ & $3.95 \pm 0.96$ & $5.71 \pm 2.27$ & $3.92 \pm 0.99$ & 0.651 & 0.578 & & \\
\hline IL-6 $(\mathrm{pg} / \mathrm{mL})^{\oint}$ & $26.9 \pm 5.19$ & $119.5 \pm 70.5^{a}$ & $12.1 \pm 3.07$ & $21.1 \pm 9.65^{a, b}$ & $24.2 \pm 8.06$ & $12.6 \pm 2.25^{b}$ & 0.054 & 0.046 & & \\
\hline IL-1 $\beta(\mathrm{pg} / \mathrm{mL})^{\oint}$ & $4.08 \pm 1.49$ & $9.32 \pm 5.54$ & $1.93 \pm 0.64$ & $2.52 \pm 1.15$ & $2.35 \pm 0.58$ & $1.87 \pm 0.60$ & 0.297 & 0.312 & & \\
\hline
\end{tabular}

Mean \pm SE. ${ }^{\oint}$ tested by logarithmic transformation, $p^{a}$-values derived from Kruskal-Wallis test at the baseline. $p^{b}$-values derived from Kruskal-Wallis test in follow-up. $p^{c}$-values derived from Kruskal-Wallis test in Changed value. $p^{d}$-values adjusted for age and sex. All alphabetical $p<0.05$ derived from Mann-Whitney U-test with Bonferroni correction; no significant differences among the groups marked by the same letter and significant differences among the groups marked with different letters. ${ }^{*} p<0.05$ derived from Willcoxon test in each group. NK: natural killer. IMHP: high-protein enteral nutrition with immune-modulating nutrients. PBMC: peripheral blood mononuclear cell. hs-CRP: high-sensitivity C-reactive protein. IL: interleukin. IFN: interferon. TNF: tumor necrosis factor. 
3.4. Relationships among Changes in BMI, Serum Albumin, Prealbumin, Cytokines, PBMC Cytokine Production, and NK Cell Activity

Correlations among the changed levels $(\Delta)$ of BMI, serum albumin, prealbumin, cytokines, PBMC cytokine production, and NK cell activity were determined after adjusting for age and gender (Figure 1 ). In 22 patients, $\Delta$ BMI positively correlated with $\Delta$ serum IL-1 $\beta$, which was positively correlated with $\Delta$ serum IL-12 and $\Delta$ PBMC IFN- $\gamma$. The net $\Delta$ of hs-CRP was strongly and negatively correlated with $\Delta$ serum prealbumin $(r=-0.831, p<0.001)$ and $\Delta$ PBMC IL-12 $(r=-0.507, p=0.016)$ (Figure 2). The net $\Delta$ of serum albumin was positively correlated with $\Delta$ PBMC TNF- $\alpha$ and $\Delta$ serum prealbumin was positively correlated with $\Delta$ NK cell activity $(\mathrm{E}: \mathrm{T}=5: 1)$ and $\Delta$ PBMC IL-12 $(r=0.590, p=0.004)$ (Figure 2). $\Delta$ NK cell activity (E:T $=5: 1)$ was strongly and positively correlated with $\Delta$ NK cell activity $(\mathrm{E}: \mathrm{T}=2.5: 1)(r=0.831, p<0.001)$ and $\Delta$ NK cell activity at both conditions was positively correlated with $\Delta$ serum prealbumin and $\Delta$ PBMC IL-12. $\Delta$ Serum TNF- $\alpha$ was positively correlated with $\Delta$ NK cell activity $(\mathrm{E}: \mathrm{T}=5: 1) . \triangle$ PBMC IL-6 was negatively correlated with $\triangle$ PBMC IL-12 and positively correlated with $\triangle$ PBMC IL-1 $\beta$ (Figure 2).

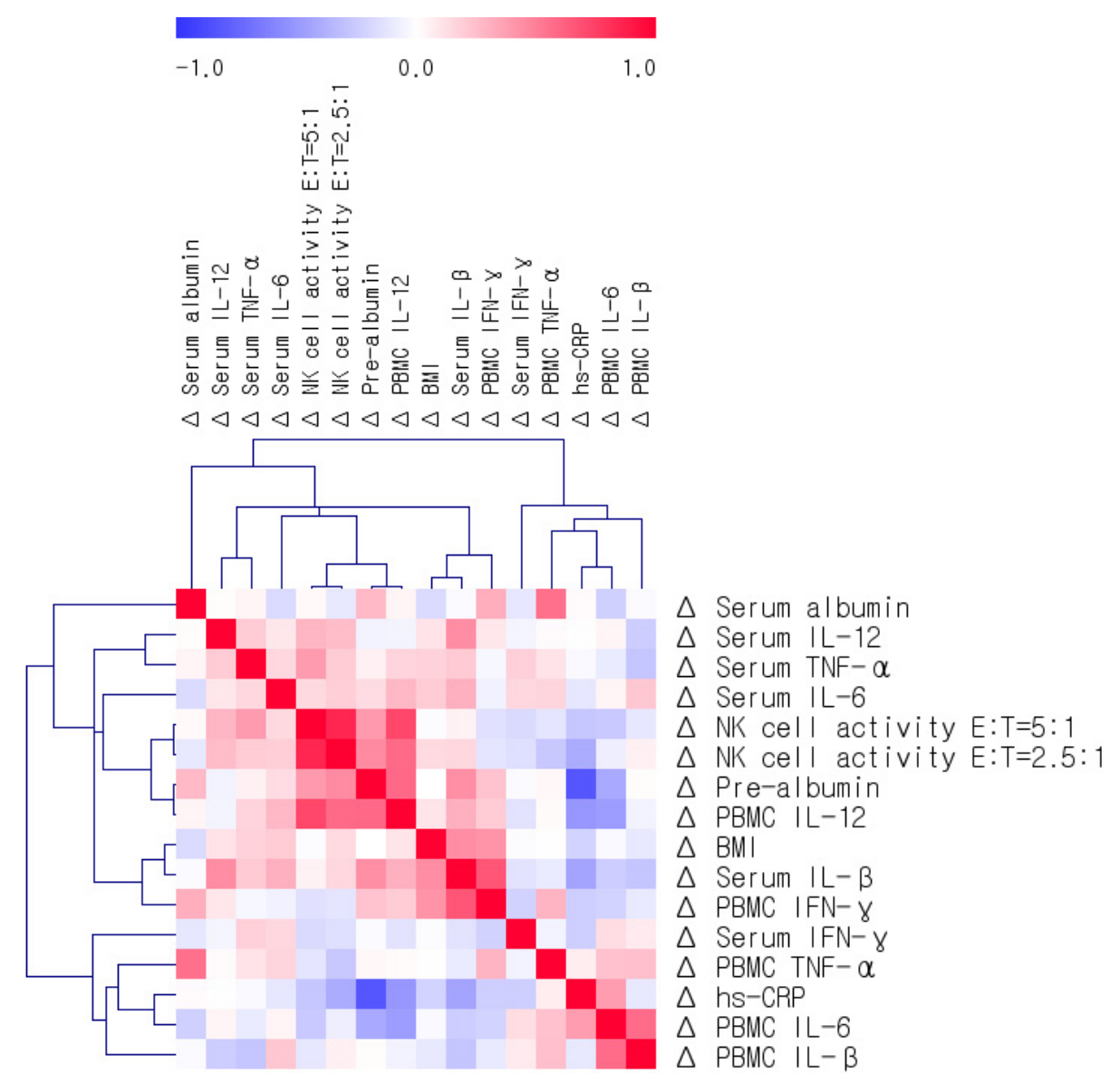

Figure 1. Matrix of correlations among changes in BMI, serum albumin, pre-albumin, cytokines, PBMC cytokine production, and NK cell activity. Correlations were obtained by deriving Spearman's correlation coefficient. Red is a positive correlation and blue is a negative correlation. 

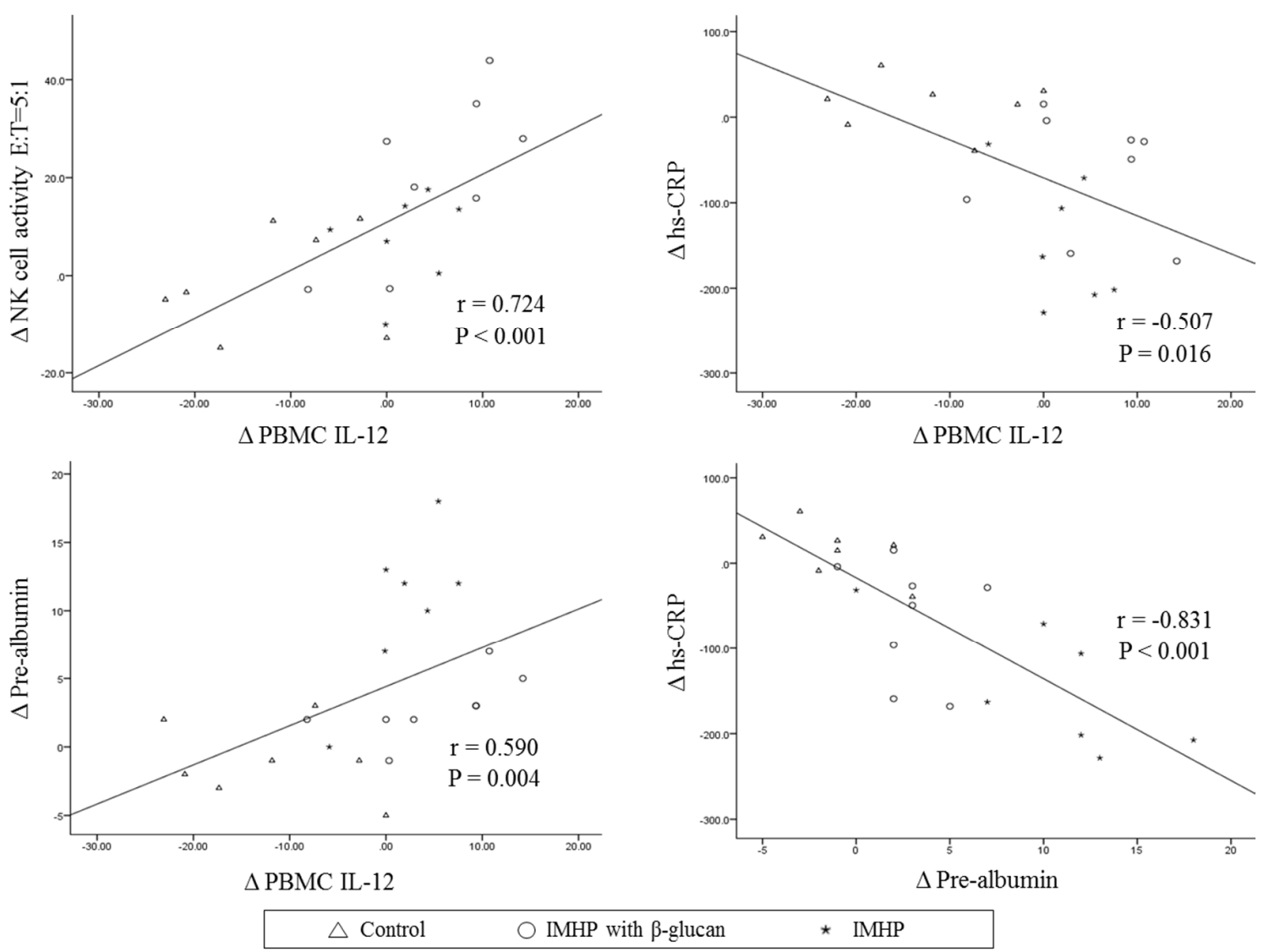

Figure 2. Correlations among changes in NK cell activity E:T = 5:1, PBMC IL-12, serum hs-CRP, and serum pre-albumin in all subjects. Tested by Spearman's correlation analysis, r: correlation coefficients.

\section{Discussion}

This randomized double-blind placebo-controlled study found beneficial effects following enteral nutrition with a combination of $\beta$-glucan $(250 \mathrm{mg} / \mathrm{L}$ ) and IMHP [high-protein ( $24 \%$ of total calories from protein). These immune-modulating nutrients (e.g., $\omega-3$ fatty acids and antioxidants) had beneficial effects on NK cell activity, a marker of immune competence [23-25], in critically ill patients known to exhibit hyporesponsiveness of NK cell activity [26]. This result is in agreement with those of a previous study in which $\beta$-glucan enhanced NK cell activation in mice $[27,28]$. Generally, the evidence in immune modulation by $\beta$-glucan is strongly supported by numerous studies $[16,17]$. However, there are few clinical studies to demonstrate the immunomodulatory effects of orally supplemented $\beta$-glucan in critically ill patients. In this clinical trial, the IMHP with the $\beta$-glucan group showed significant increases in NK cell activities at 5:1 or 2.5:1 E:T ratios from the baseline, and a significantly greater increase was seen in those at the 5:1 E:T ratio than in the control group. Additionally, an increase in NK cell activity at a ratio of E:T $=2.5: 1$ showed a greater tendency in the IMHP with $\beta$-glucan group than the control group after adjusting for age and gender. These results could suggest a synergistic effect of $\beta$-glucan on enhanced NK cell activity following seven days of feeding of IMHP enriched with $\beta$-glucan in comparison with IMHP without $\beta$-glucan.

The recent report that NK cells have beneficial anti-infection and anti-inflammatory properties [29] supports the idea that therapeutic immune intervention in critically ill patients could stimulate the function of NK cells [30]. The immunostimulating effect of $\beta$-glucan is associated with the activation of NK cells, macrophages, and T-helper (Th) cells [5]. Activated macrophages/monocytes release IL-12, which may exert a protective effect in critically ill patients through the IL-12-induced increase in cellular immunity and phagocytic functions [31]. In the control group of this study, IL-12 release from PBMC significantly decreased from the baseline, but the IMHP with $\beta$-glucan group showed a slight 
but not significant increase in PBMC IL-12 production and serum IL-12 concentration. Additionally, changes in NK cell activities were positively correlated with changes in PBMC IL-12 levels.

IL-12 positively regulates IFN- $\gamma$ secretion by NK cells, which is a major source of IFN- $\gamma$, a potent immune stimulatory cytokine [25]. In this study, however, there were no significant changes in the serum and PBMC levels of IFN- $\gamma$, TNF- $\alpha$, IL- 6 , and IL- $1 \beta$ in the IMHP groups with and without $\beta$-glucan. Additionally, changes in PBMC IL-12 were negatively correlated with changes in serum hs-CRP. Furthermore, the IMHP groups with and without $\beta$-glucan showed a greater reduction in hs-CRP than the control group, which showed the highest serum hs-CRP and PBMC IL-6 production among the three groups at seven days and increased leukocyte counts from the baseline. IMHP groups with and without $\beta$-glucan contained $3.3 \mathrm{~g} / \mathrm{L} \omega-3$ fatty acids, which are known to suppress leukocyte numbers, cytokine production, and lymphocyte proliferation [32]. Therefore, the lack of changes in serum and PBMC IFN- $\gamma$, TNF- $\alpha$, IL-6, and IL-1 $\beta$, even with increased NK-cell activities in the IMHP with $\beta$-glucan group, could be related to the intake of $\omega-3$ fatty acid.

Changes in serum levels of hs-CRP were negatively correlated with changes in serum prealbumin. As expected, serum prealbumin indicated higher protein intake in the IMHP groups with and without $\beta$-glucan ( $24 \%$ of total calorie intake from protein) than in the control group ( $20 \%$ of total calorie intake from protein). Additionally, changes in serum prealbumin were positively correlated with changes in PBMC IL-12, one of the Th1 cytokines, to increase cellular immunity [31]. These results partly support previous findings that nutrition therapy in critically ill patients plays an important role in assisting recovery and improving outcomes [32-36]. In spite of the small sample size of 22 critically ill patients, this randomized double-blind placebo-controlled study clearly showed beneficial effects following a combination of $\beta$-glucan ( $250 \mathrm{mg} / \mathrm{L})$ and IMHP [high-protein ( $24 \%$ of total calorie from protein) enteral nutrition of immune-modulating nutrients (e.g., $\omega-3$ fatty acids and antioxidants)] on NK cell activity, a marker of immune competence, without significant changes in serum and PBMC levels of IFN- $\gamma$, TNF- $\alpha$, IL- 6 , and IL-1 $\beta$. Additionally, a strong positive correlation between changes in NK cell activity and changes in PBMC IL-12, which were negatively correlated with changes in hs-CRP, suggests that $\beta$-glucan could be an attractive candidate to be added to IMHP for the stimulation of protective immunity without enhancing inflammation. Further investigations are required to evaluate the effect of $\beta$-glucan on mortality and complication rates in larger long-term trials.

\section{Conclusions}

Immune-enhancing enteral nutrition enriched with $\beta$-glucan showed significant increases in NK cell activities from the baseline and a significantly greater increase than the control group. IMHP with and without $\beta$-glucan had greater increases in serum albumin and decreases in hs-CRP than the control group. The control group had a greater decrease in PBMC IL-12 production than the IMHP groups with and without $\beta$-glucan. This study showed the beneficial effects of a combination treatment of $\beta$-glucan and IMHP on NK cell activity, and suggested that $\beta$-glucan could be an attractive candidate to add to IMHP for stimulation of protective immunity without enhanced inflammation.

Acknowledgments: This research was carried out with the support of the Bio-Synergy Research Project (NRF-2012M3A9C4048762) of the Ministry of Science, ICT and Future Planning through the National Research Foundation, Republic of Korea, the Ministry of Trade, Industry, and Energy (MOTIE), the Korea Institute for Advancement of Technology (KIAT) through the Promoting Regional Specialized Industry, and the Cooperative Research Program for Agriculture Science \& Technology Development (Project title: "Development of functional material for immune enhancement using Weissella cibaria", Project No.: PJ010835), Rural Development Administration, Republic of Korea.

Author Contributions: Sample collection and experiments were performed by Jae Gil Lee, Young Sam Kim, Young Ju Lee, Hyeon Yeong Ahn, Min Jung Cho, and Jong Ho Lee. Data were analyzed and interpreted by Jae Gil Lee, Minkyung Kim, Minjoo Kim, and Jong Ho Lee. Jong Ho Lee provided the research funding, and Minkyung Kim, Minjoo Kim, and Jong Ho Lee wrote the manuscript. All of the authors read, commented on, and contributed to the submitted manuscript.

Conflicts of Interest: The authors declare no conflict of interest. 


\section{Abbreviations}

The following abbreviations are used in this manuscript:

$\begin{array}{ll}\text { BEE } & \text { basal energy expenditure } \\ \text { BMI } & \text { body mass index } \\ \text { BUN } & \text { blood urea nitrogen } \\ \text { E } & \text { effector cell } \\ \gamma \text {-GTP } & \text { gamma-glutamyl transpeptidase } \\ \text { GOT } & \text { glutamic oxalacetic transaminase } \\ \text { GPT } & \text { glutamic pyruvate transaminase } \\ \text { HDL } & \text { High-density lipoprotein } \\ \text { hs-CRP } & \text { high-sensitivity C-reactive protein } \\ \text { ICU } & \text { intensive care unit } \\ \text { IFN } & \text { interferon } \\ \text { IL } & \text { interleukin } \\ \text { IMHP } & \text { high-protein enteral nutrition with immune-modulating nutrients } \\ \text { LDL } & \text { Low-density lipoprotein } \\ \text { NK } & \text { natural killer } \\ \text { PBMC } & \text { peripheral blood mononuclear cell } \\ \text { T } & \text { target cell } \\ \text { TNF } & \text { tumor necrosis factor }\end{array}$

\section{References}

1. Kreymann, K.G.; Berger, M.M.; Deutz, N.E.; Hiesmayr, M.; Jolliet, P.; Kazandjiev, G.; Nitenberg, G.; van den Berghe, G.; Wernerman, J.; DGEM (German Society for Nutritional Medicine); et al. ESPEN guidelines on enteral nutrition: Intensive care. Clin. Nutr. 2006, 25, 210-223. [CrossRef] [PubMed]

2. McClave, S.A.; Martindale, R.G.; Vanek, V.W.; McCarthy, M.; Roberts, P.; Taylor, B.; Ochoa, J.B.; Napolitano, L.; Cresci, G.; A.S.P.E.N. Board of Directors; et al. Guidelines for the provision and assessment of nutrition support therapy in the adult critically ill patient: Society of Critical Care Medicine (SCCM) and American Society for Parenteral and Enteral Nutrition (A.S.P.E.N). JPEN J. Parenter. Enteral Nutr. 2009, 33, 277-316. [CrossRef] [PubMed]

3. Hegazi, R.A.; Wischmeyer, P.E. Clinical review: Optimizing enteral nutrition for critically ill patients-A simple data-driven formula. Crit. Care 2011, 15, 234. [CrossRef] [PubMed]

4. Calder, P.C. n-3 Fatty acids, inflammation, and immunity-Relevance to postsurgical and critically ill patients. Lipids 2004, 39, 1147-1161. [CrossRef] [PubMed]

5. Liu, M.; Li, J.; Kong, F.; Lin, J.; Gao, Y. Induction of immunomodulating cytokines by a new polysaccharide-peptide complex from culture mycelia of Lentinus edodes. Immunopharmacology 1998, 40, 187-198. [CrossRef]

6. Ren, L.; Perera, C.; Hemar, Y. Antitumor activity of mushroom polysaccharides: A review. Food Funct. 2012, 3, 1118-1130. [CrossRef] [PubMed]

7. Vetvicka, V.; Vashishta, A.; Saraswat-Ohri, S.; Vetvickova, J. Immunological effects of yeast- and mushroom-derived beta-glucans. J. Med Food. 2008, 11, 615-622. [CrossRef] [PubMed]

8. Dai, X.; Stanilka, J.M.; Rowe, C.A.; Esteves, E.A.; Nieves, C., Jr.; Spaiser, S.J.; Christman, M.C.; Langkamp-Henken, B.; Percival, S.S. Consuming Lentinula edodes (Shiitake) Mushrooms Daily Improves Human Immunity: A Randomized Dietary Intervention in Healthy Young Adults. J. Am. Coll. Nutr. 2015, 34, 478-487. [CrossRef] [PubMed]

9. Ostadrahimi, A.; Ziaei, J.E.; Esfahani, A.; Jafarabadi, M.A.; Movassaghpourakbari, A.; Farrin, N. Effect of beta glucan on white blood cell counts and serum levels of IL-4 and IL-12 in women with breast cancer undergoing chemotherapy: A randomized double-blind placebo-controlled clinical trial. Asian Pac. J. Cancer Prev. 2014, 15, 5733-5739. [CrossRef] [PubMed]

10. Kirmaz, C.; Bayrak, P.; Yilmaz, O.; Yuksel, H. Effects of glucan treatment on the Th1/Th2 balance in patients with allergic rhinitis: A double-blind placebo-controlled study. Eur. Cytokine Netw. 2005, 16, 128-134. [PubMed]

11. Bergendiova, K.; Tibenska, E.; Majtan, J. Pleuran ( $\beta$-glucan from Pleurotus ostreatus) supplementation, cellular immune response and respiratory tract infections in athletes. Eur. J. Appl. Physiol. 2011, 111, 2033-2040. [CrossRef] [PubMed] 
12. Vetvicka, V.; Richter, J.; Svozil, V.; Rajnohová Dobiášová, L.; Král, V. Placebo-driven clinical trials of yeast-derived $\beta-(1-3)$ glucan in children with chronic respiratory problems. Ann. Transl. Med. 2013, 1, 26. [PubMed]

13. Richter, J.; Svozil, V.; Král, V.; Rajnohová Dobiášová, L.; Stiborová, I.; Vetvicka, V. Clinical trials of yeast-derived $\beta-(1,3)$ glucan in children: Effects on innate immunity. Ann. Transl. Med. 2014, 2, 15. [PubMed]

14. Mantovani, M.S.; Bellini, M.F.; Angeli, J.P.; Oliveira, R.J.; Silva, A.F.; Ribeiro, L.R. beta-Glucans in promoting health: Prevention against mutation and cancer. Mutat. Res. 2008, 658, 154-161. [CrossRef] [PubMed]

15. Murphy, E.A.; Davis, J.M.; Carmichael, M.D. Immune modulating effects of $\beta$-glucan. Curr. Opin. Clin. Nutr. Metab. Care 2010, 13, 656-661. [CrossRef] [PubMed]

16. Akramiene, D.; Kondrotas, A.; Didziapetriene, J.; Kevelaitis, E. Effects of beta-glucans on the immune system. Medicina (Kaunas) 2007, 43, 597-606. [PubMed]

17. Zeković, D.B.; Kwiatkowski, S.; Vrvić, M.M.; Jakovljević, D.; Moran, C.A. Natural and modified $(1 \rightarrow 3)$-beta-D-glucans in health promotion and disease alleviation. Natural and modified $(1 \rightarrow 3)$-beta-D-glucans in health promotion and disease alleviation. Crit. Rev. Biotechnol. 2005, 25, 205-230. [CrossRef] [PubMed]

18. Knaus, W.A.; Draper, E.A.; Wagner, D.P.; Zimmerman, J.E. APACHE II: A severity of disease classification system. Crit. Care Med. 1985, 13, 818-829. [CrossRef] [PubMed]

19. Dellinger, R.P.; Carlet, J.M.; Masur, H.; Gerlach, H.; Calandra, T.; Cohen, J.; Gea-Banacloche, J.; Keh, D.; Marshall, J.C.; Parker, M.M.; et al. Surviving Sepsis Campaign Management Guidelines Committee. Surviving Sepsis Campaign guidelines for management of severe sepsis and septic shock. Crit. Care Med. 2004, 32, 858-873. [CrossRef] [PubMed]

20. Dellinger, R.P.; Levy, M.M.; Carlet, J.M.; Bion, J.; Parker, M.M.; Jaeschke, R.; Reinhart, K.; Angus, D.C.; Brun-Buisson, C.; Beale, R.; et al. Surviving Sepsis Campaign: International guidelines for management of severe sepsis and septic shock: 2008. Crit. Care Med. 2008, 36, 296-327. [CrossRef] [PubMed]

21. ClinicalTrials.gov. Available online: http://www.clinicaltrials.gov (accessed on 4 October 2015).

22. Donaldson-Andersen, J.; Fitzsimmons, L. Metabolic requirements of the critically ill, mechanically ventilated trauma patient: Measured versus predicted energy expenditure. Nutr. Clin. Pract. 1998, 13, 25-31. [CrossRef]

23. Moretta, A.; Bottino, C.; Mingari, M.C.; Biassoni, R.; Moretta, L. What is a natural killer cell? Nat. Immunol. 2002, 3, 6-8. [CrossRef] [PubMed]

24. Weiss, G.; Meyer, F.; Matthies, B.; Pross, M.; Koenig, W.; Lippert, H. Immunomodulation by perioperative administration of n-3 fatty acids. Br. J. Nutr. 2002, 87, S89-S94. [CrossRef] [PubMed]

25. Forel, J.M.; Chiche, L.; Thomas, G.; Mancini, J.; Farnarier, C.; Cognet, C.; Guervilly, C.; Daumas, A.; Vély, F.; Xéridat, F.; et al. Phenotype and functions of natural killer cells in critically-ill septic patients. PLoS ONE 2012, 7, e50446. [CrossRef] [PubMed]

26. Kjaergaard, A.G.; Nielsen, J.S.; Tønnesen, E.; Krog, J. Expression of NK cell and monocyte receptors in critically ill patients-potential biomarkers of sepsis. Scand. J. Immunol. 2015, 81, 249-258. [CrossRef] [PubMed]

27. Pelizon, A.C.; Kaneno, R.; Soares, A.M.; Meira, D.A.; Sartori, A. Immunomodulatory activities associated with beta-glucan derived from Saccharomyces cerevisiae. Physiol. Res. 2005, 54, 557-564. [PubMed]

28. Yatawara, L.; Wickramasinghe, S.; Nagataki, M.; Takamoto, M.; Nomura, H.; Ikeue, Y.; Watanabe, Y.; Agatsuma, T. Aureobasidium-derived soluble branched $(1,3-1,6)$ beta-glucan (Sophy beta-glucan) enhances natural killer activity in Leishmania amazonensis-infected mice. Korean J. Parasitol. 2009, 47, 345-351. [CrossRef] [PubMed]

29. Souza-Fonseca-Guimaraes, F.; Adib-Conquy, M.; Cavaillon, J.M. Natural killer (NK) cells in antibacterial innate immunity: Angels or devils? Mol. Med. 2012, 18, 270-285. [CrossRef] [PubMed]

30. Narni-Mancinelli, E.; Jaeger, B.N.; Bernat, C.; Fenis, A.; Kung, S.; De Gassart, A.; Mahmood, S.; Gut, M.; Heath, S.C.; Estellé, J.; et al. Tuning of natural killer cell reactivity by NKp46 and Helios calibrates T cell responses. Science 2012, 335, 344-348. [CrossRef] [PubMed]

31. Wu, H.P.; Shih, C.C.; Chu, C.M.; Huang, C.Y.; Hua, C.C.; Liu, Y.C.; Chuang, D.Y. Effect of interleukin-17 on in vitro cytokine production in healthy controls and patients with severe sepsis. J. Formos. Med. Assoc. 2015, 114, 1250-1257. [CrossRef] [PubMed] 
32. Mukaro, V.R.; Costabile, M.; Murphy, K.J.; Hii, C.S.; Howe, P.R.; Ferrante, A. Leukocyte numbers and function in subjects eating $n-3$ enriched foods: Selective depression of natural killer cell levels. Arthritis Res. Ther. 2008, 10, R57. [CrossRef] [PubMed]

33. Calder, P.C.; Jensen, G.L.; Koletzko, B.V.; Singer, P.; Wanten, G.J. Lipid emulsions in parenteral nutrition of intensive care patients: Current thinking and future directions. Intensive Care Med. 2010, 36, 735-749. [CrossRef] [PubMed]

34. Ott, J.; Hiesgen, C.; Mayer, K. Lipids in critical care medicine. Prostaglandins Leukot. Essent. Fatty Acids 2011, 85, 267-273. [CrossRef] [PubMed]

35. Barros, K.V.; Cassulino, A.P.; Schalch, L.; Della Valle Munhoz, E.; Manetta, J.A.; Calder, P.C.; Flor Silveira, V.L. Pharmaconutrition: Acute fatty acid modulation of circulating cytokines in elderly patients in the ICU. JPEN J. Parenter. Enter. Nutr. 2014, 38, 467-474. [CrossRef] [PubMed]

36. Giger, U.; Büchler, M.; Farhadi, J.; Berger, D.; Hüsler, J.; Schneider, H.; Krähenbühl, S.; Krähenbühl, L. Preoperative immunonutrition suppresses perioperative inflammatory response in patients with major abdominal surgery-a randomized controlled pilot study. Ann. Surg. Oncol. 2007, 14, 2798-2806. [CrossRef] [PubMed]

(C) 2016 by the authors; licensee MDPI, Basel, Switzerland. This article is an open access article distributed under the terms and conditions of the Creative Commons Attribution (CC-BY) license (http:/ / creativecommons.org/licenses/by/4.0/). 